\title{
Diversity and structure of microcrustacean assemblages (Cladocera and Copepoda) and limnological variability in perennial and intermittent pools in a semi-arid region, Bahia, Brazil
}

\author{
Nadson R. Simões ${ }^{1}$, Sylvia M. M. S. Ribeiro ${ }^{2} \&$ Sérgio L. Sonoda $^{3}$ \\ 1. Pós-Graduação em Ecologia de Ambientes Aquáticos Continentais, Universidade Estadual de Maringá. Av. Colombo, 5790, Bloco G-90, 87020-900, Maringá, PR Brazil. (nadsonressye@yahoo.com.br) \\ 2. Departamento de Biologia, Universidade Estadual Santa Cruz, Rodovia Ilhéus - Itabuna Km 16, 45662-000, Ilhéus, BA Brazil. (ssusini@uesc.com.br) \\ 3. Departamento de Biologia, Universidade Estadual do Sudoeste da Bahia, Av. José Moreira Sobrinho, 45200-000, Jequié, BA Brazil. (sonodasl@terra.com.br)
}

\begin{abstract}
Temporary wetlands undergo recurrent drought due to the scarcity of water, which disrupts the hydrological connectivity with adjacent aquatic systems. However, some environments retain water for longer periods, allowing greater persistence of the community. The current study evaluated differences in the microcrustacean assemblages and limnological variability between perennial and intermittent pools in a semi-arid region of Brazil. The abiotic features (water temperature, $\mathrm{pH}$, total alkalinity, electrical conductivity and depth) of intermittent pools were affected more than perennial pools due to loss of water volume. This may have contributed to a higher average richness and diversity index in some intermittent pools and differences in the structure of the assemblages. The lowest species richness and diversity were recorded where physical factors, such as a large quantity of suspended solids and variability in the electrical conductivity of the water and $\mathrm{pH}$, make the environment unsuitable for these organisms. These results suggest that community development in intermittent pools is interrupted by the dry season; when the water returns, due to rainfall or rising groundwater, each pond undergoes a different process of colonization. In these circumstances, the biological importance of temporary aquatic environments is clear, since such pools provide shelters and have an important role in the maintenance of the regional diversity of aquatic environments.
\end{abstract}

KEYWORDS. Zooplankton, temporary wetlands, invertebrates, "caatinga".

RESUMO. Diversidade, estrutura da assembleia de microcrustáceos (Cladocera e Copepoda) e variabilidade limnológica em poças perenes e intermitentes na região semiárida, Bahia, Brasil. Ambientes temporários sofrem secas periódicas devido à escassez de água que interrompe a conectividade hidrológica com sistemas aquáticos adjacentes. No entanto, alguns ambientes retem água por mais tempo permitindo uma maior persistência das comunidades. Este estudo avaliou diferenças nas assembleias de microcrustáceos e na variabilidade limnológica entre poças perenes e temporárias em um rio intermimente na região semiárida da Bahia. As características abióticas das poças temporárias (temperatura da água, $\mathrm{pH}$, alcalinidade total, condutividade elétrica e profundidade) foram mais afetadas do que nas poças perenes devido à perda total do volume de água. Isso pode ter contribuído para maior riqueza e índice de diversidade médio de microcrustáceos em alguns ambientes intermitentes, e a diferenças encontradas na estrutura das assembleias. Menores valores de diversidade e riqueza de espécies foram registrados nos locais com fatores físicos e químicos restritivos que tornaram o ambiente impróprio para os organismos, tais como: maior quantidade de sólidos em suspensão e condutividade elétrica da água e amplitude de variação do $\mathrm{pH}$. Estes resultados sugerem que nos ambientes intermitentes, o desenvolvimento da comunidade é interrompido pela estação seca. Quando a água retorna, devido às chuvas ou soerguimento do lençol freático, cada ambiente apresenta um processo diferente de colonização. Nestas circunstâncias, a importância biológica dos ambientes aquáticos temporários é destacada, já que esses locais fornecem abrigos e têm um papel importante na manutenção da diversidade regional de ambientes aquáticos.

PALAVRAS-CHAVE. Zooplâncton, rios temporários, invertebrados, caatinga.

Temporary wetlands undergo recurrent drought periods (WiLliams, 1987), are distributed worldwide (Boulton \& Lake, 1990; Stanley et al., 1997; Gasith \& Resh, 1999; Medeiros \& MaltchiK, 2001; Townsend, 2002), and play an important role in the maintenance of biodiversity since they are a haven for many communities (Williams, 1997; Schwartz \& JeNKINS, 2000).

Water scarcity in these environments disrupts hydrological connectivity and fragments the environment into several sub-systems, each with their own functional dynamic and structural characteristics (GrIMM, 1994; LAKE, 2003). Since these depend on their abiotic and biotic structure, these sub-systems establish patches (Townsend, 1989; Poole, 2002) that respond differently to water shortage. Understanding the dynamics of such patches is a challenge to researchers because it involves an intricate interaction between abiotic and biotic features, related to the buffering capacity caused by physical and chemical disturbances.

Temporary wetlands are affected by local and regional seasonality, such as rainfall, evaporation, runoff, infiltration, hydroperiod (permanence of surface water), and exchanges with the groundwater (Williams, 1987; Boulton \& LAKE, 1992). Evaporation during the dry season reduces the volume of the water body and affects the availability and quality of the resources (JUNK, 2002; LAKE, 2003). These variations constrain the potential pool of community members by eliminating species that are unable to cope with the resulting physical stress (WELLBORn et al., 1996).

Aquatic microcrustaceans are influenced by the physical environment (Dodson, 1992), chemical features of the water (CotTENIE et al., 2001; SCHell et al., 2001; KrYLOv, 2004), and by biotic interactions with the local community (SChefFer, 1998; Hobaek et al., 2002). These organisms play an important role in the metabolism of aquatic ecosystems due to their intermediate position in the food chain. Thus, they can be influenced by both top-down and bottom-up processes. Aquatic microcrustaceans tend to be highly diversified in temporary environments due to their high adaptive plasticity to cope with environmental fluctuations. The current study aimed to verify differences in the diversity, structure and composition of microcrustacean 
assemblages between temporary and perennial pools, in order to assess the hypothesis that perennial and intermittent pools have different microcrustacean assemblages as the former are less limnologically variable than the latter.

\section{MATERIAL AND METHODS}

Study area. The Jequiezinho River Basin, JRB (Fig. 1), with a drainage area of $1,339 \mathrm{~km}^{2}$, lies in the semi-arid region of Brazil, between 13\%40' $-13^{\circ} 50^{\prime} \mathrm{S}$ and $40^{\circ} 17^{\prime}-41^{\circ} 06^{\prime} \mathrm{W}$. The vegetation, popularly known as 'caatinga', is characterized by arboreal and shrubby deciduous plants, including xerophytic species. The mean monthly precipitation varies from $50 \mathrm{~mm}$ in the dry season (May to October) to $95 \mathrm{~mm}$ in the rainy season (November to April). Under these circumstances, pools of different sizes are frequently formed along the stream bed.

Sampling was carried out monthly, between September 2002 and August 2003, in six pools distributed across the JRB. These pools contained few riparian plants and a low frequency of aquatic macrophytes (emerging, free-floating, submersed, and floating leaves) throughout the year. During the sampling period, three pools dried up and were thus classified as temporary (T1, T2 and T3); water was constantly present in P1, P2 and P3, and thus these pools were termed perennial. The depth of perennial pools ranged from $0.3 \mathrm{~m}$ to $1.3 \mathrm{~m}$, while in temporary pools it ranged from 0 (when dried up) to 0.6 $\mathrm{m}$. Two temporary pools dried up for 5 months, and one for 2 months. Water flow was only observed in P2, P3 and T1 during October, November and December.

Sampling data. Samples of microcrustaceans were collected for qualitative analyses by horizontal tows using a plankton net $(68 \mu \mathrm{m})$. For quantitative analyses,
$100 \mathrm{~L}$ of water were retrieved in a plastic bucket, filtered through the plankton net and preserved in $4 \%$ formalin. The organisms were identified to the genus or species level using an optical microscope and a specialized bibliography (REID, 1985; MATSUMURA-TuNDISI, 1986; Elmoor-Loureiro, 1997; Rocha, 1998; AleKseev, 2002). Water temperature, $\mathrm{pH}$ (QUIMIS, Q-400A), total alkalinity (GolTERMAN et al., 1978), dissolved oxygen (Winkler modified by GolTERMAn et al., 1978), electrical conductivity (Digimed-DM3), depth, total suspended solids (TSS), inorganic suspended solids, organic suspended solids, and the presence of aquatic macrophytes were recorded during the study period.

Data analysis. Given that environmental variability is an inherent characteristic of temporary environments, it was investigated as a limiting factor in the development of the community. Thus, the variability in limnological features between perennial and intermittent pools was calculated using the coefficient of variation (CV). The Mann-Whitney test was used to identify differences in the $\mathrm{CV}$ between the two types of environment (perennial and intermittent).

Diversity measurements consisted of species richness and the Shannon index (KREBS, 1999). We also plotted a rarefaction curve to compare species richness regardless of the effect of abundance (GoTELLI \& Colwell, 2001). The temporal (months) and spatial (pools) frequency of occurrence was calculated according to the percentage of each species. Species richness and diversity were differentiated by analysis of variance (ANOVA). The Least Significant Difference test (LSD) was used post-hoc and the differences were considered significant at $\mathrm{p}<0.05$.

In order to test differences in assemblage structures, multivariate analyses were carried out. The sampling sites were ordinated using Non-metric

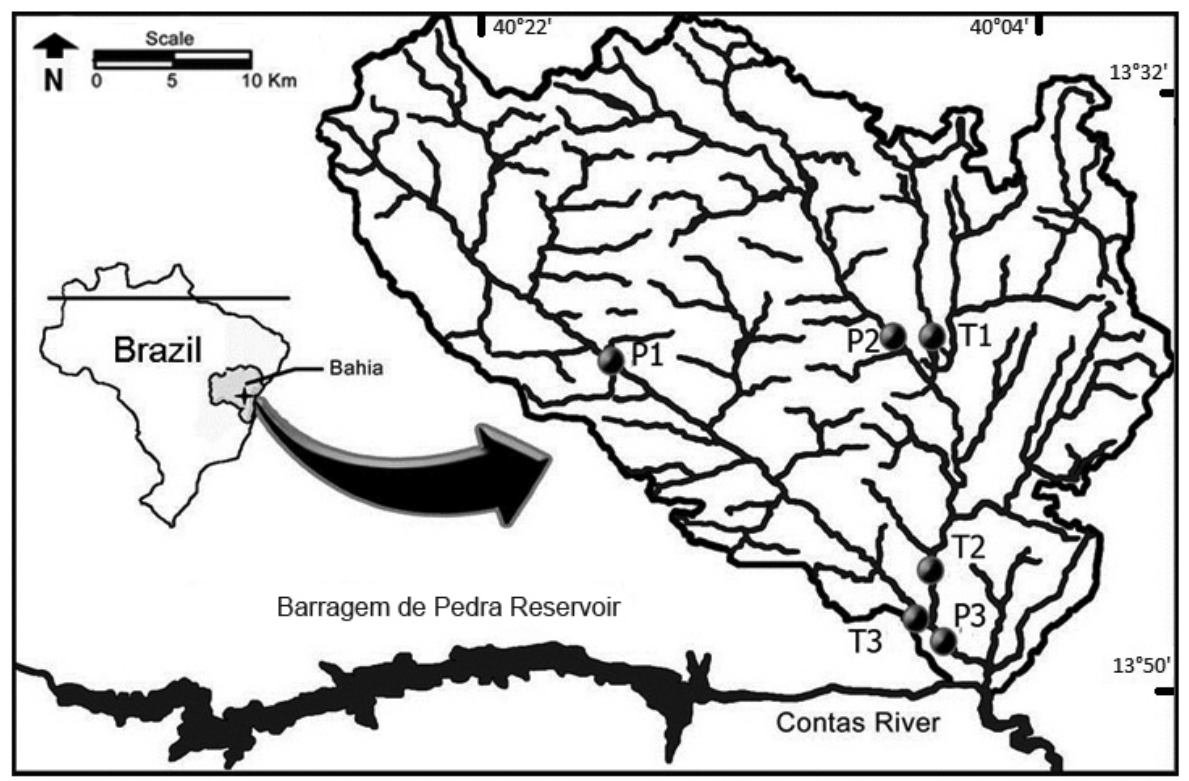

Fig. 1. Study area with sampling sites in the Jequiezinho River Basin, state of Bahia, Brazil. 
Multidimensional Scaling - NMDS (using a matrix of Bray-Curtis distances), which does not make assumptions about the distribution of species abundance (ClaRKe, 1993). Assemblage structure was differentiated using a permutational multivariate analysis of variance (Permanova) (ANDERson, 2001).

The association between assemblage structure and abiotic data was determined using a redundancy analysis - RDA (LegendRe \& Legendre, 1998). The significance of the associations between assemblage structure and abiotic data were estimated using a permutational test, assessing the null hypothesis of no relationship between the two matrices, to determine whether the variation could be distinguished from random (LEGENDRE et al., 2011).

Species richness and abundance data were transformed into $\log _{2}(x+1)$ to achieve normality and stabilize the variance. For the RDA, abiotic data were standardized. Multivariate analyses (NMDS, Permanova and RDA) were conducted using free software $\mathrm{R}$ version 2.8.1 (R Development Core Team, 2008), and the Shannon diversity index was calculated using the free software PAST version 1.74 (HAMmer et al., 2001).

\section{RESULTS}

Water temperature ranged from $20.4^{\circ} \mathrm{C}$ (T2) to $33.5^{\circ} \mathrm{C}$ (P3) (Tab. I). Electrical conductivity ranged between $2260 \mu \mathrm{S} . \mathrm{cm}^{-1}$ (T1) and $10210 \mu \mathrm{S} . \mathrm{cm}^{-1}$ (T3). Total alkalinity varied between 0.1 meq. $\mathrm{L}^{-1}$ (T2) and 5.3 meq. $\mathrm{L}^{-1}$ (T1). Dissolved oxygen ranged from $1.9 \mathrm{mg} . \mathrm{L}^{-1}$ (P1) to $18.7 \mathrm{mg} . \mathrm{L}^{-1}$ (T3). The $\mathrm{pH}$ value ranged between 6.3 (T3) and 9.02 (T3). The minimum amount of suspended solids was $3.40 \mathrm{mg} . \mathrm{L}^{-1}$, whilst the maximum was $746.67 \mathrm{mg} . \mathrm{L}^{-1}$, with the highest values at sites $\mathrm{T} 2$ and $\mathrm{T} 3$.
Electrical conductivity, dissolved oxygen, depth and suspended solids had a higher coefficient of variation throughout the year than water temperature, $\mathrm{pH}$ and total alkalinity (Tab. I). The Mann-Whitney test detected significant differences in the coefficients of variation between the two types of environment (perennial and intermittent) with regard to the following characteristics: $\mathrm{pH}$, total alkalinity, electrical conductivity and depth. These results implied higher limnological variability in intermittent pools than in perennial environments.

Twenty-eight microcrustacean taxa were identified: 10 Cladocera, 3 Copepoda Calanoida and 15 Copepoda Cyclopoida (Tab. II). Ceriodaphnia cornuta Sars, 1886, Latonopsis australis Sars, 1888, Microcyclops anceps Richard, 1897, Notodiaptomus iheringi Wright, 1935, Notodiaptomus cearensis Wright, 1936, Halicyclops venezuelaensis Lindberg, 1954, and Microcyclops alius Kiefer, 1935 occurred in the majority of pools sampled (Tab. III). Only four species (L. australis in $\mathrm{P} 1$ and $\mathrm{P} 2 ; M$. alius in $\mathrm{P} 1, \mathrm{~T} 1$ and $\mathrm{P} 3$; C. cornuta and Moinodaphnia macleayi King, 1853 in T1) occurred with a temporal frequency of occurrence of more than $50 \%$ (Tab. III).

Regardless the number of individuals, species richness was higher in T1 and T2 (Fig. 2). Likewise, the average species richness and diversity were highest in T1, whilst the lowest values occurred in T3 (Figs 3, 4). ANOVA showed significant differences in richness $(F=$ $5.62 ; p=0.00)$ and diversity $(F=3.14 ; p=0.01)$ among pools. The LSD test showed larger differences among intermittent than perennial pools. However, richness and diversity did not differ between perennial and temporary pools $(p>0.05)$ because the variance among temporary pools was high.

The NMDS showed slight separation between

Tab. I. Summary of the physical and chemical water features in pools in the Jequiezinho River Basin, state of Bahia, Brazil, September 2002 to August 2003. WT, water temperature $\left({ }^{\circ} \mathrm{C}\right)$; TA, total alkalinity $\left(\mu\right.$ eq. $\left.\mathrm{L}^{-1}\right) ; \mathrm{EC}$, electrical conductivity $\left(\mu \mathrm{S} . \mathrm{cm}^{-1}\right)$; DO, dissolved oxygen $\left(\mathrm{mg} . \mathrm{L}^{-1}\right)$; Dp, depth $(\mathrm{m})$; TSS, total suspended solids (mg. $\left.\mathrm{L}^{-1}\right)$; OSS, organic suspended solids (mg. $\left.\mathrm{L}^{-1}\right)$; ISS, inorganic suspended solids (mg.L $\left.{ }^{-1}\right)$; CV, coefficient of variation. * Significant differences in the variation coefficient between perennial and intermittent pools (Mann-Whitney test; $\mathrm{p}<0.05)$.

\begin{tabular}{|c|c|c|c|c|c|c|c|c|c|c|}
\hline & & WT & $\mathrm{pH}^{*}$ & $\mathrm{TA}^{*}$ & $\mathrm{EC}^{*}$ & DO & Dp* & TSS & OSS & ISS \\
\hline \multirow[t]{3}{*}{ P1 } & Minimum & 21.6 & 7.3 & 1.0 & 2940 & 1.9 & 0.3 & 5.8 & 3.8 & 1.6 \\
\hline & Maximum & 26.7 & 7.9 & 3.9 & 6860 & 9.9 & 0.9 & 25.4 & 13.1 & 12.3 \\
\hline & $\mathrm{CV}$ & 8 & 20 & 3 & 29 & 44 & 52 & 47 & 53 & 46 \\
\hline \multirow[t]{3}{*}{ P2 } & Minimum & 21.5 & 7.3 & 2.3 & 4070 & 4.8 & 0.4 & 8.4 & 5.8 & 2.6 \\
\hline & Maximum & 29.7 & 8.3 & 4.2 & 5255 & 15.4 & 1.3 & 193.3 & 139.3 & 54.0 \\
\hline & $\mathrm{CV}$ & 10 & 10 & 4 & 18 & 36 & 42 & 124 & 83 & 154 \\
\hline \multirow[t]{3}{*}{ P3 } & Minimum & 24.5 & 7.5 & 2.0 & 4270 & 6.6 & 0.3 & 5.8 & 3.8 & 2.0 \\
\hline & Maximum & 33.5 & 8.1 & 3.5 & 7850 & 13.5 & 0.6 & 17.4 & 11.2 & 10.8 \\
\hline & $\mathrm{CV}$ & 10 & 19 & 3 & 17 & 21 & 20 & 28 & 56 & 34 \\
\hline \multirow[t]{3}{*}{$\mathrm{T} 1$} & Minimum & 23.1 & 6.5 & 0.5 & 2260 & 2.0 & 0.0 & 3.4 & 1.8 & 1.2 \\
\hline & Maximum & 31.3 & 8.0 & 5.3 & 6780 & 11.6 & 0.6 & 46.6 & 21.3 & 28.3 \\
\hline & $\mathrm{CV}$ & 11 & 23 & 8 & 63 & 66 & 58 & 99 & 130 & 87 \\
\hline \multirow[t]{3}{*}{$\mathrm{T} 2$} & Minimum & 20.4 & 7.3 & 0.1 & 4020 & 4.5 & 0.0 & 7.8 & 4.2 & 1.4 \\
\hline & Maximum & 32.4 & 8.4 & 2.4 & 9480 & 16.6 & 0.5 & 746.7 & 513.3 & 233.3 \\
\hline & $\mathrm{CV}$ & 6 & 34 & 5 & 82 & 40 & 58 & 157 & 154 & 159 \\
\hline \multirow[t]{3}{*}{$\mathrm{T} 3$} & Minimum & 24.1 & 6.3 & 0.2 & 5460 & 5.4 & 0.0 & 37.5 & 11.7 & 19.0 \\
\hline & Maximum & 32.4 & 9.0 & 3.4 & 10210 & 18.7 & 0.3 & 600.0 & 360.0 & 260.0 \\
\hline & $\mathrm{CV}$ & 11 & 21 & 11 & 84 & 33 & 53 & 68 & 61 & 76 \\
\hline
\end{tabular}


Tab. II. Microcrustacean (Cladocera and Copepoda) species recorded in pools in the Jequiezinho River Basin, state of Bahia, Brazil, September 2002 to August 2003.

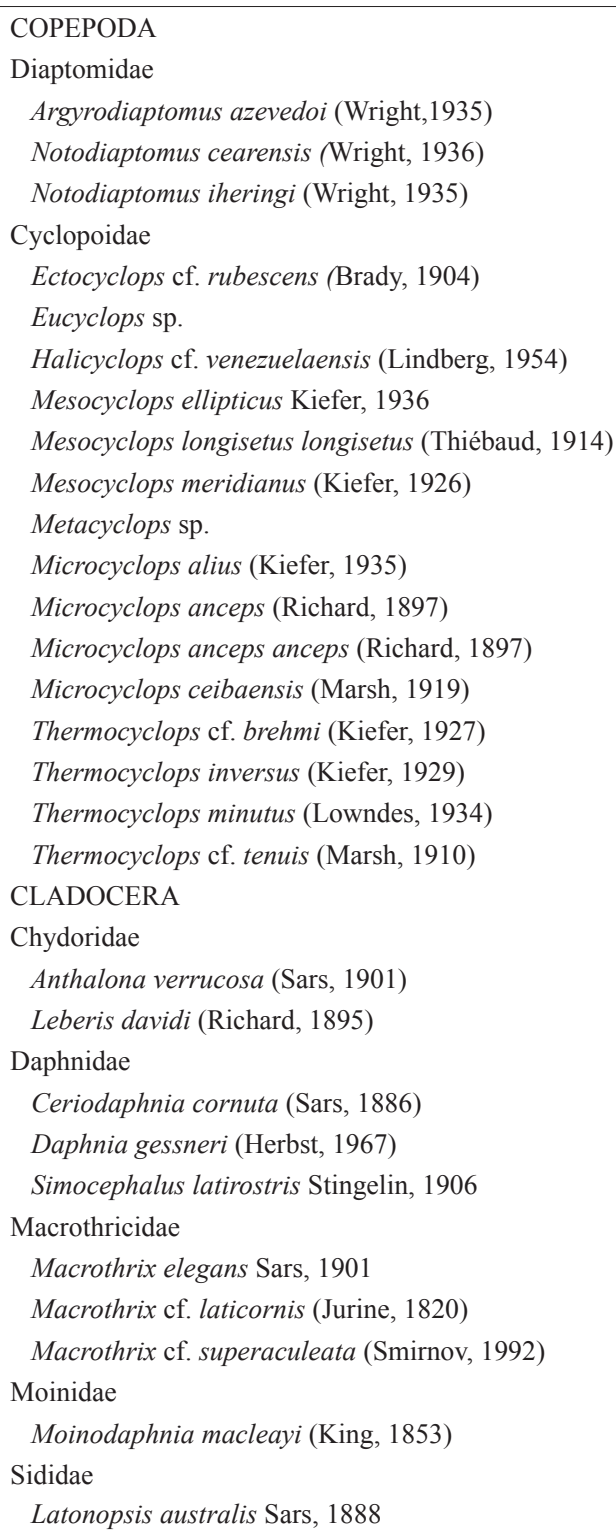

temporary and perennial samples (Fig. 5). Furthermore, assemblage structure differed between perennial and temporary pools (Permanova, Pseudo-F $=2.60 ; \mathrm{p}=$ 0.013). Macrothrix and Thermocyclops were more frequent in temporary pools, while Daphnia gessneri only occurred in perennial pools. The redundancy analysis revealed that assemblage structure was associated with environmental variability $(p<0.005)$, with $26 \%$ of the inertia constrained, but a high unconstrained value (74\%) (Tab. IV). The environmental variables that were significantly $(\mathrm{p}<0.05)$ associated with constrained inertia were water temperature, dissolved oxygen, inorganic suspended solids and depth (Tab. IV). $M$. alius was more common when water temperature and suspended inorganic solids were low. On the other hand, L. australis was positively correlated with inorganic suspended solids.

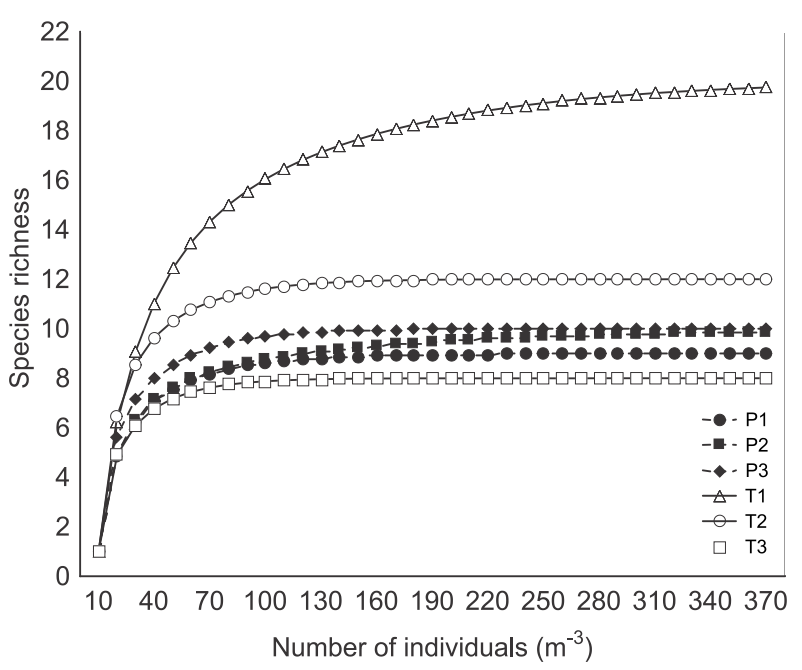

Fig. 2. Rarefaction curves of the microcrustacean species from Jequiezinho River Basin in perennial and temporary pools.

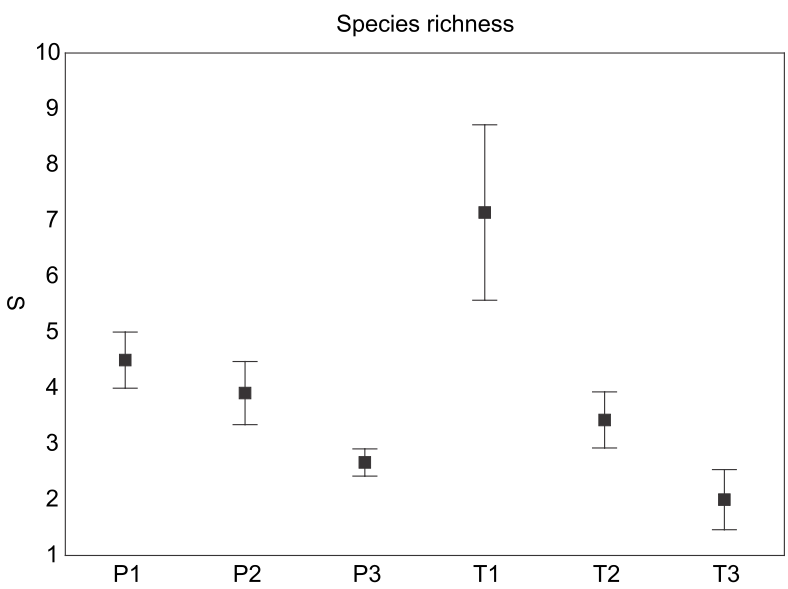

Fig. 3. Mean species richness (S) in pools in the Jequiezinho River Basin, state of Bahia, Brazil between September 2002 and August 2003 (Bars, standard error; P, perennial pool; T, temporary pool).

\section{DISCUSSION}

Seasonal variation and local conditions affect the environmental characteristics and quality of temporary aquatic systems, according to changes in the hydroperiod (Williams, 1999; FAHD et al., 2000; TAVERNINI et al., 2005), which probably cause sudden variations in the trophic state of the water. The seasonal fluctuation in JRB was marked by depth variation due to hydric stress, leading to a reduction in water volume by evaporation and promoting the loss of habitat (GRIMM, 1994; STANLEY et al., 1997; GAsith \& RESH, 1999). However, the biotic and abiotic features of the intermittent pools were more severely affected by the loss of total water volume (Boulton \& LAKE, 1990); intermittent pools (T1, T2 and T3) showed higher variability in chemical and physical water characteristics, and greater differences in diversity and community structure.

Latonopsis australis and M. alius showed the highest spatial and temporal frequency of occurrence in JRB, suggesting that they are physiologically adjusted 
Tab. III. Temporal frequency of occurrence of Cladocera and Copepoda in perennial (P) and temporary (T) pools in the Jequiezinho River Basin, state of Bahia, Brazil, during 2002-2003.

\begin{tabular}{|c|c|c|c|c|c|c|}
\hline & P1 & P2 & P3 & $\mathrm{T} 1$ & $\mathrm{~T} 2$ & $\mathrm{~T} 3$ \\
\hline \multicolumn{7}{|l|}{ COPEPODA } \\
\hline Argyrodiaptomus azevedoi & 8.3 & 8.3 & - & 14.3 & - & 10.0 \\
\hline Notodiaptomus cearensis & 16.7 & 16.7 & 16.7 & - & 28.6 & 10.0 \\
\hline Notodiaptomus iheringi & 16.7 & 8.3 & 25.0 & 14.3 & 14.3 & 20.0 \\
\hline Eucyclops sp. & - & - & - & 28.6 & - & - \\
\hline Ectocyclops cf. rubensces & 33.3 & - & 16.7 & 42.9 & 14.3 & - \\
\hline Halicyclops venezuelaensis & 8.3 & 50.0 & 41.7 & - & 28.6 & 30.0 \\
\hline Mesocyclops ellipticus & - & - & - & 28.6 & - & - \\
\hline Mesocyclops longisetus longisetus & - & - & - & 28.6 & - & - \\
\hline Mesocyclops meridianus & - & - & - & 28.6 & 42.9 & 10.0 \\
\hline Mesocyclops sp. & 41.7 & - & - & 57.1 & 14.3 & - \\
\hline Microcyclops alius & 66.7 & 41.7 & 58.3 & 71.4 & 42.9 & - \\
\hline Microcyclops cebaiensis & - & - & 25.0 & - & - & - \\
\hline Microcyclops anceps & 8.3 & 8.3 & 8.3 & 14.3 & 28.6 & 20.0 \\
\hline Microcyclops anceps anceps & - & 16.7 & - & - & 28.6 & - \\
\hline Thermocyclops inversus & 8.3 & - & - & - & 28.6 & 10.0 \\
\hline Thermocyclops minutus & - & - & - & 14.3 & - & - \\
\hline Thermocyclops $\mathrm{cf}$. tenuis & - & - & - & 28.6 & - & - \\
\hline Thermoyclops cf. brehmi & 8.3 & - & - & - & - & - \\
\hline \multicolumn{7}{|l|}{ CLADOCERA } \\
\hline Anthalona verrucosa & - & - & 16.7 & 28.6 & 28.6 & - \\
\hline Leberis davidi & - & - & - & 42.9 & - & - \\
\hline Ceriodaphnia cornuta & 41.7 & 33.3 & 8.3 & 85.7 & 14.3 & 20.0 \\
\hline Daphnia gessneri & 16.7 & 8.3 & 8.3 & - & - & - \\
\hline Latonopsis australis & 91.7 & 66.7 & 25.0 & 42.9 & 14.3 & - \\
\hline Macrothrix cf. laticornis & - & - & - & 14.3 & - & - \\
\hline Macrothrix cf. superaculeata & - & - & - & 14.3 & - & - \\
\hline Macrothrix elegans & - & - & - & 14.3 & - & - \\
\hline Moinodaphnia macleayi & - & - & 8.3 & 57.1 & - & - \\
\hline Simocephalus latirostris & - & - & - & 42.9 & 14.3 & - \\
\hline
\end{tabular}

Table IV. Summary of redundancy analysis: partitioning of variance, contribution of the first three axes, and environmental vectors fitted. * Permutation test with p-value $<0.05$.

\begin{tabular}{|c|c|c|c|}
\hline Partitioning of variance & Inertia & & Proportion \\
\hline Total & 25.000 & & 1.000 \\
\hline Constrained & $6.616^{*}$ & & 0.265 \\
\hline Unconstrained & 18.384 & & 0.735 \\
\hline Contribution of the first three axes & Axis 1 & Axis 2 & Axis 3 \\
\hline Eigenvalue & $2.655^{*}$ & $0.997 *$ & $0.816^{*}$ \\
\hline Proportion Explained & 0.106 & 0.039 & 0.032 \\
\hline Cumulative Proportion & 0.106 & 0.146 & 0.178 \\
\hline Environmental vectors fitted & $\mathrm{R}^{2}$ & & P - Value \\
\hline Water temperature & 0.144 & & 0.05 \\
\hline $\mathrm{pH}$ & 0.060 & & 0.70 \\
\hline Total alkalinity & 0.047 & & 0.12 \\
\hline Dissolved oxygen & 0.260 & & 0.02 \\
\hline Total solids suspended & 0.188 & & 0.49 \\
\hline Organic solids suspended & 0.185 & & 0.05 \\
\hline Inorganic solids suspended & 0.162 & & 0.03 \\
\hline Electric conductivity & 0.221 & & 0.07 \\
\hline Depth & 0.113 & & 0.01 \\
\hline
\end{tabular}




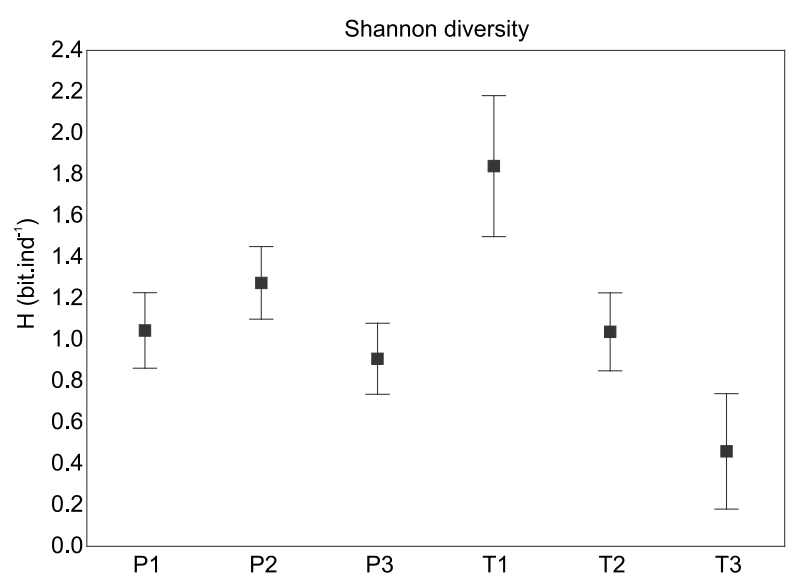

Fig. 4. Mean Shannon diversity index $(\mathrm{H})$ in pools in the Jequiezinho River Basin, state of Bahia, Brazil between September 2002 and August 2003 (Bars, standard error; P, perennial pool; T, temporary pool).

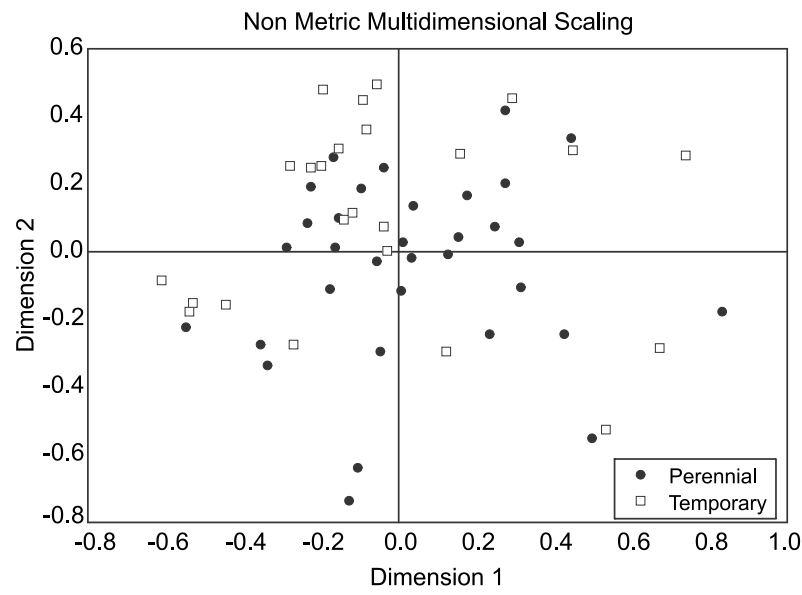

Fig. 5. Non metric multidimensional scaling (NMDS) of the microcrustacean assemblages showing the temporal ordination of assemblage structure in the Jequiezinho River Basin, state of Bahia, Brazil between September 2002 and August 2003.

to tolerate variations in the temporary environment. The processes responsible for the distribution of the organisms in temporary water bodies are not clear. Experimental studies have suggested that these processes are associated with the arrival and persistence of the organisms within a particular body of water (HoLLAND \& Jenkins, 1998). The distribution of organisms in temporary wetlands is the result of a complex interaction between biotic and abiotic factors, determined by local and regional processes (Shurin, 2000; Cottenie \& De Meester, 2003; TAVERnini, 2008).

In terms of local processes, the heterogeneity of substrates and contraction of the physical environment intensify the inter- and intra-species interactions that play a primary role in the structure of communities (GAsith \& Resh, 1999). This was observed in current study, in which many restricted species were found in T1, where the highest diversity of aquatic macrophytes was recorded. On the other hand, the physical restriction in T3 (with no aquatic macrophytes and high variation in physical and chemical factors) resulted in a poorly developed community.
Calanoid copepods were sporadic in the JRB due to unfavorable conditions for the development of these taxa in environments with high hydric constraints. This may be related to the copepods' life cycle and adjustments to more stable environments. According to NogueIRA (2001), calanoid copepods are K-strategists with a longer growth period and the need for more stable environmental conditions for the development of their populations than those required by cyclopoid copepods. The sporadic peaks in the abundance of calanoids indicated sudden improvements in environmental conditions after high levels of rainfall (Shiel et al., 1998; Freitas \& CRISPIM, 2005).

Differences in the species richness and diversity index are the result of spatial and temporal heterogeneity (GrimM, 1994). The pools with the highest species richness (T1, P1 and P2) had the most developed pelagic and marginal regions, with high temporal variation in the aquatic vegetation (mainly in T1). Thus, the temporal variations underlying the hydrological regime occurring during the year changed the spatial heterogeneity of the environment and established temporal niches for different species. Depending on their limits of tolerance, they will eventually be substituted according to the availability and suitability of niches, therefore increasing local diversity. Similarly, within the power of several functions, the hydrology in areas that flood affects multiple and interacting variables to provide colonist species and to create the conditions that favor the hatching of propagules and the differential persistence of populations (MEDLEY \& HAVEL, 2007).

The presence of aquatic macrophytes contributes towards the growth of local diversity since they were shown to play an important role in the structure and dynamics of the microcrustacean assemblages by increasing their diversity (richness and abundance) in shallow aquatic environments (SCHEFFER et al., 2006), and in a water reservoir in a semi-arid region (VIEIRA et al., 2009). They provide the zooplankton community shelter and protection against predators such as fish and macroinvertebrates (SCHEFFER, 1998), reduce predation and disturbances in the system (CARDINALE et al., 1998), and favor an increase in the number of species due to high niche availability (FAHD et al., 2000; COTTENIE et al., 2001; Cottenie \& De Meester, 2003).

On the other hand, low rates of diversity and richness (T3 and P3) may be caused by physical factors, such as a large quantity of suspended solids and variability in the electrical conductivity and $\mathrm{pH}$ of the water, which make the environment unsuitable for these organisms. In general, diversity tends to decline in physically controlled ecosystems in which physical and chemical characteristics are limiting factors, and increase in biologically controlled ecosystems.

The highest species richness was observed in the upstream sampling sites. Studies that recorded a similar pattern (KRYLOV, 2004; MwEBAZA-NDAWULA et 
al., 2005; Thorp \& MANTOvani, 2005) attributed this to the higher quality of the upstream locations. This study corroborated this hypothesis, with the upstream locations being far from urbanization, and presenting the lowest values of electrical conductivity and total suspended solids, and the greatest depths (SIMÕES et al., 2008).

Permanova showed differences in the structure of the assemblages. However, the differences were greatest among intermittent pools. This reflects the different responses to the hydric stress to which intermittent pools are subjected, resulting in high levels of differentiation among their communities. Different processes of species colonization in intermittent pools contribute towards their dissimilarity (JENKINS \& BUIKEMA JR, 1998; Cottenie \& De Meester, 2003).

As demonstrated by the Mann-Whitney test, other studies have also reported a high variability in environmental characteristics in intermittent pools (Meintjes et al., 1994; Scholnick, 1994; Podrabsky et al., 1998). This would lead to different responses of the microcrustacean assemblages between perennial and intermittent pools (Seminara et al., 2008). However, we found that the assemblage structure was associated with the environmental gradient (RDA, significant constrained inertia). A correlation between the physical and chemical features and microcrustaceans in shallow and temporary wetlands was also recorded by COTTENIE et al. (2001), Schell et al. (2001), Krylov (2004), Mwebasa-Ndawula et al. (2005) and Tavernini et al. (2005).

In temporary environments, organisms undergo strong natural selection (NIX \& JENKINS, 2000; SCHWARTZ $\&$ JENKINS, 2000) and the assemblages are a result of the interactions between the frequency and intensity of the disturbances. There is little information on temporary tropical streams in Brazil, although they are ecologically interesting because of their spatial and temporal variability, and may be appropriate for the development and application of ecological theories. Moreover, these temporary habitats may provide a habitat for important assemblages of rare and/or endangered species and support assemblages that differ from those of permanent water bodies. Temporary wetlands have been considered as biodiversity hotspots (LAKE, 2003; TAVERNINI, 2008).

The results demonstrated that microcrustacean assemblages and limnological variability differ in perennial and intermittent pools. Further, in the case of intermittent pools, assemblages differ among themselves because community development is interrupted by the dry season; when the water returns, due to rainfall or rising groundwater, each pond undergoes a different process of colonization. Under these circumstances, the biological importance of the temporary aquatic environments is clear, since such pools provide shelter and play an important role in the maintenance of the regional diversity of aquatic environments.
Acknowledgements. We thank the Universidade Estadual do Sudoeste da Bahia (UESB) and Universidade Estadual de Santa Cruz (UESC) for logistic support, and Coordenação de Aperfeiçoamento de Pessoal de Ensino Superior (CAPES), for a scholarship to the first author.

\section{REFERENCES}

Alekseev, V. R. 2002. Copepoda. In: Fernando, C. H. ed. A guide to tropical freshwater zooplankton: Identification, ecology and impact on fisheries. Leiden, Backhuys Publishers. p. 123-187.

ANDERSON, M. J. 2001. A new method for non-parametric multivariate analysis of variance. Austral Ecology 26:32-46.

Boulton, A. J. \& Lake, P. S. 1990. The ecology of two intermittent streams in Victoria, AI. Multivariate analyses of physicochemical features. Freshwater Biology 24:123-141.

1992. The ecology two intermittent stream in Victoria, AII. Comparisons of faunal composition between habitats, rivers and years. Freshwater Biology 27:99-121.

Cardinale, B. J.; Brady, V. J. \& Burton, T. M. 1998. Changes in the abundance e diversity of coastal wetland fauna from the open water/macrophytes edge towards shore. Wetlands Ecology and Management 6:59-68.

Clarke, K. R. 1993. Non-parametric multivariate analyses of changes in community structure. Australian Journal of Ecology 18:117143.

Cottenie, K. \& De Meester, L. 2003. Connectivity and cladoceran species richness in a metacommunity of shallow lakes. Freshwater Biology 48:823-832.

Cottenie, K.; Nuytten, N.; Michels, E. \& De Meester, L. 2001. Zooplankton community structure and environmental conditions in a set of interconnected ponds. Hydrobiologia 442:339-350.

Dodson, S. 1992. Predicting crustacean zooplankton species richness. Limnology and Oceanography 37(4):848-856.

Elmoor-Loureiro, L. M. A. 1997. Manual de identificação de cladóceros limnicos do Brasil. Brasília, Universa. 155p.

Fahd, K.; Serano, L. \& Toja, J. 2000. Crustacean and rotifer composition of temporary ponds in the Doñana National Park (SW Spain) During Floods. Hydrobiologia 436:41-49.

Freitas, G. T. \& Crispim, M. C. 2005. Seasonal effects on zooplanktonic community in a temporary lagoon of northeast Brazil. Acta Limnologica Brasiliensia 17(4):385-393.

Gasith, A. \& Resh, V. H. 1999. Stream in Mediterranean climate regions: abiotic influences and biotic to predictable seasonal events. Annual Review Ecology and Systematics 30:51-81.

Golterman, H. L; Clymo, R. S. \& Ohmstad, M. A. M. 1978. Methods for Physical and Chemical Analysis of Fresh Waters. Oxford, Blackwell Scientific. 213p.

Gotelli, N. J. \& Cowell, R. K. 2001. Quantifying biodiversity: procedures and pitfalls in the measurement and comparison of species richness. Ecology Letters 4:379-391.

Grimm, N. B. 1994. Disturbance, succession and ecosystem processes in streams: a case study from the desert. In: GiLler, P. S.; HildREW A. G. \& Raffaelli, D. G. eds. Aquatic ecology: scale, pattern and process. London, Blackwell Science. p. 93-112.

Hammer, O.; Harper, D. A. T. \& Ryan, P. D. 2001. Palaeontological Statistics software package for education and analysis. Palaeontologia Electronica 4(1):1-9.

Hobaek, A.; Manca, M. \& Andersen, T. 2002. Factors influencing species richness in lacustrine zooplankton. Acta Oecologica 23:155-163.

Holland, T. A. \& Jenkins, D. G. 1998. Comparison of processes regulating zooplankton assemblages in new freshwater pools. Hydrobiologia 387/388:207-214.

Jenkins, D. G. \& Buikema JR., A. R. 1998. Do similar communities develop in similar sites? A test with zooplankton structure and function. Ecological Monograph 68(3):421- 444.

JuNK, W. J. 2002. Long-term environmental trends and the future of tropical wetlands. Environmental Conservation 29:414-435.

KreBs, C. J. 1999. Ecological methodology. New York, Benjamin/ Cummings. 581p.

KRYLOV, A. V. 2004. Distribution of zooplankton along the longitudinal profile of two disturbed small rivers of the upper Volga Basin. Russian Journal of Ecology 35:358-365.

LAKE, P. S. 2003. Ecological of perturbation by drought in flowing water. Freshwater Biology:1161-1172. 
Legendre, P. \& Legendre, L. 1998. Numerical Ecology. Amsterdam, Elsevier Science. 853p.

Legendre, P.; Oksanen, J. \& ter Braak, C. J. F. 2011. Testing the significance of canonical axes in redundancy analysis. Methods in Ecology and Evolution 2:269-277.

Matsumura-Tundisi, T. 1986. Latitudinal distribution of Calanoida copepods in freshwater aquatic systems of Brazil. Revista Brasileira de Biologia 43(3):527-553.

Medeiros, E. S. F. \& MaltchiK, L. 2001. Fish assemblage stability in an intermittently flowing stream from the Brazilian semiarid region. Austral Ecology 26:156-164.

MedLey, K. A. \& Havel, J. E. 2007. Hydrology and local environmental factors influencing zooplankton communities in floodplain ponds. Wetlands 27(4):864-872.

Meintjes, S.; Seaman, M. T. \& KoK, D. J. 1994. Duration of inundation and change in physical and chemical characteristics of small temporary pans in South Africa. Hydrobiologia 281:79-90.

Mwebaza-Ndawula, L.; Sekiranda, S. B. K. \& Kiggundu, V. 2005. Variability of zooplankton along a section of the upper Victoria Nile, Uganda. African Journal of Ecology 43:251-257.

NIX, M. H. \& Jenkins, D. G. 2000. Life history comparisons of Daphnia obtusa from temporary ponds and fed low-quality food. Aquatic Ecology 34:19-27.

NogueirA, M. G. 2001. Zooplankton composition, dominance and abundance as indicators of environmental compartmentalization in Jurumirim Reservoir (Paranapanema River), São Paulo, Brazil. Hydrobiologia 455:1-18.

Podrabsky, J. E.; Hrbek, T. \& Hand, S. C. 1998. Physical and chemical characteristics of ephemeral pond habitats in the Maracaibo basin and Llanos region of Venezuela. Hydrobiologia 362:67-78.

Poole, G. C. 2002. Fluvial landscape ecology: addressing uniqueness within the river discontinuum. Freshwater Biology 47:641-660.

R Development Core Team. 2008. R: A language and environment for statistical computing. $\mathrm{R}$ Foundation for Statistical Computing, Vienna, Austria. Available at: $<$ http://www.R-project. org $>$. Accessed on: 01.2011.

REID, J. W. 1985. Chave de identificação e lista de referências bibliográficas para as espécies continentais sul-americanas de vida livre da ordem Cyclopoida (Crustacea, Copepoda). Boletim de Zoologia 9:17-143.

Rocha, C. E. F. 1998. New morphological characters useful for the taxonomy of the genus Microcyclops (Copepoda, Cylopoida). Journal of Marine Systems 15:425-431.

SCHEFFER, M. 1998. Ecology of Shallow Lakes. London, Chapman e Hall. $358 \mathrm{p}$.

SCheffer, M.; VAn Geest, G. J.; Zimmer, K.; Jeppesen, E.; SondergaArd, M.; Butler, M. G.; Hanson, M. A.; Declerck, S. \& De Meester L. 2006. Small habitat size isolation can promote species richness: second-order effects on biodiversity in shallow lakes and ponds. Oikos 112:227-231.
Schell, J. M.; SAntos-Flores, C.; Allen, P. E.; Hunker, B. M.; Kloehn, S.; Michelson, A.; Lillie, R. A. \& Dodson, S. 2001. I. Physical-chemical influences on vernal zooplankton community structure in small lakes and wetlands of Wisconsin, U. S. A. Hydrobiologia 445:37-50.

ScholNick, D. 1994. Seasonal variation and diurnal fluctuations in ephemeral desert pools. Hydrobiologia 294:111-116.

SChwARTZ, S. S. \& JENKINS, D. J. 2000. Temporary aquatic habitats: constraints and opportunities. Aquatic Ecology 34:3-8.

Seminara, M.; Vagaggini, D. \& Margaritora, F. G. 2008. Differential responses of zooplankton assemblages to environmental variation in temporary and permanent ponds. Aquatic Ecology 42:129-140.

Simões, N. R.; Sonoda, S. L. \& Ribeiro, S. M. M. S. 2008. Spatial and seasonal variation of microcrustaceans (Cladocera and Copepoda) in intermittent rivers in the Jequiezinho River Hydrographic Basin, in the Neotropical semiarid. Acta Limnologica Brasiliensia 3: 197-204.

Shiel R. J.; Green, J. D. \& Nielsen, D. L. 1998. Floodplain biodiversity: why are there so many species? Hydrobiologia 387/388:39-46.

ShurIN, J. B. 2000. Dispersal limitation, invasion resistance, and the structure of pond zooplankton communities. Ecology 81:3074-3086.

Stanley, E. H.; Fisher, S. G. \& Grimm, N. B. 1997. Ecosystem expansion and contraction in streams. Bioscience 47:427-435.

TAVERNINI, S. 2008. Seasonal and inter-annual zooplankton dynamics in temporary pools with different hydroperiods. Limnologica 38:63-75.

Tavernini, S.; Mura, G. \& Rossetti, G. 2005. Factors influencing the Seasonal Phenology and Composition of Zooplankton communities in Mountain Temporary Pools. International Review of Hydrobiology 90(4):358-357.

Thorp, J. H. \& MANTOVAnI, S. 2005. Zooplankton of turbid and hydrologically dynamic prairie rivers. Freshwater Biology 50:1474-1491.

Townsend, C. R. 1989. The patch dynamics concept of stream community ecology. Journal of the North American Benthological Society 8:36-50.

Townsend, S. A. 2002. Seasonal evaporative concentration of a extremely turbid water body in the semiarid tropics of Australia. Lakes \& Reservoir 7:103-107.

Vieira, A. C. B.; Ribeiro, L. L.; Santos, D. P. N. \& Crispim, M. C. 2009. Correlation between the zooplanktonic community and environmental variables in a reservoir from the Northeastern semi-arid. Acta Limnologica Brasiliensia 21(3):349-358.

Wellborn, G. A.; Skelly D. K. \& Werner, E. E. 1996. Mechanisms creating community structure across a freshwater habitat gradient. Annual Review of Ecology and Systematics 27:337-363.

Williams, D. D. 1987. The ecology of temporary waters. London, Croom Helm. 205p.

1997. Temporary ponds and their invertebrate communities. Aquatic Conservation 7:105-117.

Williams, W. D. 1999. Conservation of wetlands in drylands: a key global issue. Aquatic Conservation 9:517-522.

Recebido em 31 de março de 2011. Aceito em 29 de dezembro de 2011. ISSN 0073-4721

Artigo disponível em: www.scielo.br/isz

Impresso e distribuído em 2012. 